\title{
IMPACT OF SOCIAL CAPITAL TOWARDS STRATEGIC CAPABILITIES OF MANUFACTURING SMES IN MALAYSIA
}

\author{
Siti Normah Awang Tuah \\ Faculty of Business and Management \\ Universiti Teknologi MARA, Cawangan Melaka, Malaysia \\ E-mail: sitinormah@uitm.edu.my \\ Noor Hazlina Ahmad \\ School of Management \\ Universiti Sains Malaysia, Penang, Malaysia \\ Hasliza Abd Halim \\ School of Management \\ Universiti Sains Malaysia, Penang, Malaysia
}

\begin{abstract}
Research on SMEs in Malaysia has become more significant nowadays as SMEs in Malaysia contribute national income to the country. Internationalisation of SMEs is imperative as smaller firms operating international business today develop their own capabilities and competitive advantage. Thus, it is important for SMEs especially those in emerging countries like Malaysia to look into their social capital and put their efforts to strategize their capabilities to respond to the global competition and business opportunities. This study was conducted to examine the impact of social capital towards the SMEs capabilities before they adopt the best strategic approach to face challenge situations at hand. A quantitative approach was employed in this study and a total of 187 responses from manufacturing SME exporters were received and further analyzed using Partial Least Square (PLS) technique. The results demonstrated that social capital of manufacturing SMEs in Malaysia has significant impact only on innovation, marketing and technology capabilities but not market-linking and management capabilities.
\end{abstract}

Keywords: Social Capital, Strategic Capabilities, Manufacturing SMEs.

\section{INTRODUCTION}

What is the impact of social capital towards strategic capabilities especially small firms? Nowadays, the interrelated of business relationship, knowledge and its development of strategy become crucial as business firms such as SMEs trying hard to expand their business internationally. They put their effort to understand their social capital and capabilities they possess to go abroad. They try to work closely with stakeholders (e.g. customers, suppliers and alliance partners) and gain knowledge from them. But, how their current social capital affects their capabilities at hand to stay competitive in the world business since they expand their business internationally? 
Recent studies pay attention to maintaining the international success of firms through connections and networking at home and abroad (Gamage et al., 2020). The social capital derived from social network act as critical resources that a firm can developed to enhance its competitive advantage (Chrisholm \& Neilsen, 2009). Therefore, the absence of social capital would be impossible for firms to compete and expand their business in the world since the social capital is embedded a network of people. The critical issue in SME sector is a large number of SMEs are closed down within a very shorter period of business commencement due to the many reasons (Prasanna et al., 2019) and Covid-19 for instant, is the most severely impacted to small firms (SMEs) business.

According to Gamage at al. (2020), previous researches are mainly in the group themes of social capital and SME performance, social capital and internationalization success, social capital and CSR-SME relationships, social capital and Family SMEs and social capital and innovation and marketing capabilities. The researchers review past literature on social capital and SME between the years 1999 to 2020.The study of social capital for SMEs is still limited even though SME is globally identified as an important strategic sector for promoting growth and social development with the use of social capital. Since only a limited number of studies have focused on innovation with the social capital and SMEs. Study on social capital and marketing capability is also a less-discussed subject.

This study is to explore the concept of social capital to manufacturing SMEs in Malaysia that actively doing business internationally. The purpose of this study is to look at the impact of Malaysian manufacturing SMEs' social capital towards their strategic capabilities at hand. The strategic capabilities include innovation, marketing and other strategic capabilities such as market-linking, technology and management capabilities.

\section{Social Capital}

\section{LITERATURE REVIEW}

Social capital is the sum of the actual knowledge and potential knowledge embedded within the networks of mutual acquaintance and recognition among employees (Nahapiet \& Goshal, 1998; Subramaniam \& Youndt, 2005). They refer to the concept of social capital as important resources, including knowledge that is available to persons through their social relations. Social capital theory also grounded in the belief that benefits are gained by individuals from the social networks (Coleman, 1988), and this applies significantly to a business context and a firm's network relationships.

Social capital theory defines "social capital" as resources created through people's social relationships that can be harnessed to achieve positive social outcomes (Bourdieu, 1986; Burt, 1992). Bourdieu's original definition of social capital draws attention to its sources and its dynamic genesis, as the creation of social capital essentially accounts for the gradual accumulation of social obligations from existing social relationships (Bondeli, 2018).

Social Capital Theory argues that relational returns can be achieved through investment in social networks (Lin, Cook, \& Burt, 2001); these returns essentially rest on the notion that individuals can profit from their interactions with others through networked relations (Krishen et al., 2019).

\section{Social Capital and Strategic Capabilities}

Innovation capability is one of the business strengths for firms to expand their business internationally. Gamage et al. (2020) also noted that SMEs use the social relationships and 
innovation abilities to achieve competitive priorities and enhancing firms' performance. There is a direct relationship between social capital and innovative capabilities (Ismail et al., 2014). Studied by Sulistoy and Ayuni (2020) on social capital for Indonesian SMEs, results show that there is an important influence of social capital on innovation and performance capacities.

The results of social capital also exist link between innovation capability and technology capability. Study by Mazzucchelli et al. (2021) for Italian manufacturing SMEs operating in mature industries with internationalised $R \& D$ activities. The results reveal the critical role of structural social capital and IT in enhancing knowledge sharing and innovation capabilities. This study suggests that collaboration among R\&D teams in different countries could also facilitate knowledge sharing and improve innovation capabilities in a mature industry. Especially for the latter internet, social media can provide firms and marketers with an immense range of opportunities for extending and preserving relations they have with customers in the real world in online communities using various technologies and marketing tools cost efficiently and effectively (Antoniadis \& Charmantzi, 2016). Technology adaptation through network relationship leads to generate benefits in the SMEs such as economies of scale, bargaining power, product differentiation, traditional and cultural identities, and input use efficiencies (Prasanna et al., 2019).

Social networking and consumers' interactions related to products' customer experience and use, have always been in the epicentre of attention for marketing a product or a brand (Antoniadis \& Charmantzi, 2016). The knowledge of marketing capabilities is also important for firms to know their level of competitiveness in their business. The application of social network in marketing can contributes especially to small firm's marketers with valuable insights for effective integrated marketing communication and business strategies. Networking is crucial for them to build good business link, relationship and market-linking with oversea marketers or business partners.

Moreover, to relate the social capital and management capabilities, Houghton, Smith, and Hood (2009) mentioned in their study that "a primary requirement for a firm to sustain a complex strategy is strong knowledge management capabilities". It is essential for firms to apply their social capital or networking to strategize their knowledge management capabilities. Thus this study also was testing to know whether their social capital contributes uniquely to their management capabilities. Social capital also potentially benefits countries in various ways, including the fostering of innovation, knowledge flow, competitiveness and trust (Doh \& Acs, 2010).

Many researchers agree that social capital is the most important strategic asset for the success of an organisation (Chang \& Hsieh, 2011; Khalique et al., 2018). There is also general agreement that this positive relationship exists within the SME context (Ismail, 2014; Khalique et al., 2018). However, what is not clear is whether this positive result holds true within a developing nation such as Malaysia. Nevertheless, Malaysian researchers in particular argue that, in their own specific context, "knowledge is a necessity and can be used as a strategic tool against competitors". These arguments lead us to come up with the following hypotheses:

H11: Social capital has a positive impact on innovation capability H12: Social capital has a positive impact on market-linking capability

H13: Social capital has a positive impact on marketing capability H14: Social capital has a positive impact on technological capability H15: Social capital has a positive impact on management capability 


\section{METHODOLOGY}

This study employed quantitative methods to examine the social capital and its impact to manufacturing SME's strategic capabilities (i.e. innovation, market-linking, and marketing, technology and management capabilities) in Malaysia. 187 questionnaires successfully received from the respondents and they were asked to select an export venture in which they were personally involved of which they have good knowledge and experience. The questionnaires distributed to respondents are included 3 sections. Section A for social capital which contained 6 items. Section B includes questions related to the manufacturing SMEs' strategic capabilities. This section consists of five dimensions namely Innovation capability, Marketing capability, Market-linking capability, Technology capability and Management capability. Each of the capabilities contained 6 items respectively which are adopted from Parnell (2015), except for Innovation capability. This variable contained 7 items that are adopted from Rosli (2012) and finally, section $\mathrm{C}$ is respondent's profile and firm background information with 10 items. The data was analysed using SPSS (Social package for Social Science) and PLS (Partial-Least Square) system.

Prior to testing the statistical significance of the paths of the measurement and structural models, we examine their validity and reliability. Specifically, the reflective measurement model involves the assessment of reliability and validity of the indicators (items). All items are significant at $\mathrm{p}=0.05$ levels with high loadings and low cross-loadings, at testing convergent validity. All AVEs are above 0.5 (AVE $=0.515$ and higher) and the items are the indicators that have high loadings and contribute to the acceptable value of $\mathrm{CR}$ ( $\mathrm{CR}>0.708$ ) to achieve adequate convergent validity as provided in Table 1.

Table 1. Summary Table of Reflective Measurement Model

\begin{tabular}{|c|c|c|c|}
\hline Construct & Loadings & AVE & CR \\
\hline $\begin{array}{l}\text { Social Capital } \\
\text { In general, our employees } \\
\ldots \text { are skilled in working together to solve problems } \\
\ldots \text {. share information and learn from one another } \\
\ldots \text {..exchange ideas with people from different areas in the } \\
\text { company } \\
\ldots \text { work closely with stakeholders (e.g. customers, suppliers } \\
\text { and alliance partners) } \\
\ldots \text { apply their job-related knowledge in their area to another } \\
\text { area in the company to solve problems } \\
\text {... apply their job-related knowledge in their area to another } \\
\text { area in the company to find new opportunities }\end{array}$ & $\begin{array}{l}0.773 \\
0.777 \\
0.766 \\
0.818 \\
0.761 \\
0.751\end{array}$ & 0.600 & 0.900 \\
\hline $\begin{array}{l}\text { Innovation Capability } \\
\text { Application of the latest technology in product } \\
\text { Introduction of new product } \\
\text { Materials sourcing from new suppliers/sources } \\
\text { Using new material combination in production } \\
\text { Employing the internet in business } \\
\text { Investing in research and development (R\&D) }\end{array}$ & $\begin{array}{l}0.688 \\
0.743 \\
0.593 \\
0.792 \\
0.793 \\
0.739\end{array}$ & 0.527 & 0.869 \\
\hline
\end{tabular}




\begin{tabular}{|c|c|c|c|}
\hline $\begin{array}{l}\text { Market-linking Capability } \\
\text { Market sensing capabilities } \\
\text { Customer-linking (i.e., creating and managing durable } \\
\text { customer relationships) capabilities } \\
\text { Capabilities of creating durable relationship with our } \\
\text { suppliers } \\
\text { Ability to retain customers } \\
\text { Channel-bonding capabilities (i.e., creating durable } \\
\text { relationship with channel members such as wholesalers and } \\
\text { retailers) } \\
\text { Relationships with channel members }\end{array}$ & $\begin{array}{l}0.723 \\
0.707 \\
0.794 \\
0.746 \\
0.816\end{array}$ & 0.575 & 0.871 \\
\hline $\begin{array}{l}\text { Marketing Capability } \\
\text { Knowledge of customers } \\
\text { Knowledge of competitors } \\
\text { Integration of marketing activities } \\
\text { Skill to segment and target markets } \\
\text { Effectiveness of pricing programs } \\
\text { Effectiveness of advertising programs }\end{array}$ & $\begin{array}{l}0.765 \\
0.794 \\
0.800 \\
0.734 \\
0.701 \\
0.727\end{array}$ & 0.569 & 0.888 \\
\hline $\begin{array}{l}\text { Technology Capability } \\
\text { New product development capabilities } \\
\text { Manufacturing processes using technology } \\
\text { Technology development capabilities } \\
\text { Ability of predicting technological changes in the industry } \\
\text { Production facilities } \\
\text { Quality control skills }\end{array}$ & $\begin{array}{l}0.720 \\
0.843 \\
0.783 \\
0.632 \\
0.823 \\
0.746\end{array}$ & 0.579 & 0.891 \\
\hline $\begin{array}{l}\text { Management Capability } \\
\text { Integrated logistics systems } \\
\text { Cost control capabilities } \\
\text { Financial management skills } \\
\text { Human resource management capabilities } \\
\text { Accuracy of profitability and revenue forecasting } \\
\text { Marketing planning process }\end{array}$ & $\begin{array}{l}0.709 \\
0.704 \\
0.716 \\
0.767 \\
0.744 \\
0.822\end{array}$ & 0.555 & 0.882 \\
\hline
\end{tabular}

\section{DISCUSSION}

The results from the analysis of respondent's profile and firm's background showed in Table 2. Majority of respondents are male, aged between 36 to 45 years old with degree education level and most of them are manager for their firms. SMEs types of business that responded for this study are private limited comes from every state in Malaysia. They have more than 10 and not exceeding 200 permanent employees thus fit to the well-established inclusionary criteria of SME.

Table 2. Respondent's profile and firm's background

\begin{tabular}{|l|l|l|}
\hline Demographic data & Frequency & Percentage \\
\hline $\begin{array}{l}\text { Gender } \\
\text { Male }\end{array}$ & 130 & 69.5 \\
\hline
\end{tabular}




\begin{tabular}{|c|c|c|}
\hline Female & 57 & 30.5 \\
\hline Age & 40 & 21.4 \\
\hline 25-35 years & 118 & 63.1 \\
\hline $36-45$ years & 29 & 15.5 \\
\hline $46-55$ years & & \\
\hline \multicolumn{3}{|l|}{ Level of Education } \\
\hline Ph.D & 2 & 1.1 \\
\hline Masters & 69 & 36.9 \\
\hline Degree & 98 & 52.4 \\
\hline Diploma & 18 & 9.6 \\
\hline \multicolumn{3}{|l|}{ Position } \\
\hline Director & 6 & 3.2 \\
\hline General Manager & 44 & 23.5 \\
\hline Manager & 72 & 38.5 \\
\hline Assistant Manager & 26 & 13.9 \\
\hline Executives & 39 & 20.9 \\
\hline \multicolumn{3}{|l|}{ Type of business } \\
\hline Sole proprietorship & 17 & 9.1 \\
\hline Partnership & 6 & 3.2 \\
\hline Private Limited & 164 & 87.7 \\
\hline \multicolumn{3}{|l|}{ Main manufacturing factory } \\
\hline Johor & 33 & 17.6 \\
\hline Melaka & 22 & 11.8 \\
\hline Negeri Sembilan & 15 & 8.0 \\
\hline Kuala Lumpur & 19 & 10.2 \\
\hline Selangor & 49 & 26.2 \\
\hline Pahang & 7 & 3.7 \\
\hline Perlis & 1 & 0.5 \\
\hline Perak & 14 & 7.5 \\
\hline Kedah & 12 & 6.4 \\
\hline Penang & 4 & 2.1 \\
\hline Kelantan & 2 & 1.1 \\
\hline Terengganu & 1 & 0.5 \\
\hline Sabah & 3 & 1.6 \\
\hline Sarawak & 5 & 2.7 \\
\hline \multicolumn{3}{|l|}{ Current permanent employees } \\
\hline $10-50$ & 73 & 39.0 \\
\hline $51-100$ & 71 & 38.0 \\
\hline $101-150$ & 18 & 9.6 \\
\hline $151-200$ & 25 & 13.4 \\
\hline$<200$ & 0 & 0 \\
\hline \multicolumn{3}{|l|}{ Years' operating } \\
\hline Less than 5 years & 18 & 9.6 \\
\hline $5-10$ years & 30 & 16.0 \\
\hline $11-15$ years & 28 & 15.0 \\
\hline $16-20$ years & 39 & 20.9 \\
\hline
\end{tabular}




\begin{tabular}{|l|l|l|}
\hline More than 20 years & 72 & 38.5 \\
\hline Type of industry & & \\
Food \& Beverages & 41 & 21.9 \\
Electrical \& Electronics & 20 & 10.7 \\
Machinery \& Engineering & 11 & 5.9 \\
Metal \& Metal products & 21 & 11.2 \\
Petrochemical \& Chemical & 7 & 3.7 \\
Non-metallic mineral products & 4 & 2.1 \\
Paper/Printing \& Publishing & 6 & 3.2 \\
Plastic \& Plastic products & 5 & 2.7 \\
Wood \& Wood products & 10 & 5.3 \\
Rubber products & 6 & 3.2 \\
Palm oil products & 1 & 0.5 \\
Transport equipment & 4 & 2.1 \\
Packaging & 2 & 1.1 \\
Textile/Clothing/Bag/Shoes & 4 & 2.1 \\
Households products & 27 & 14.4 \\
Pharmaceuticals/Cosmetics & 10 & 5.3 \\
Others ((i.e. Fertilizer) & 8 & 4.3 \\
\hline Countries export (Companies can tick more than one & & \\
category) & 136 & 72.7 \\
South East Asia & 110 & 58.8 \\
East Asia & 28 & 15.0 \\
South Asia & 45 & 24.1 \\
Europe & 29 & 15.5 \\
North America & 44 & 23.5 \\
Middle East & 10 & 5.3 \\
Africa & \\
\hline
\end{tabular}

Furthermore, majority of the SMEs operating their business for more than 20 years from different types of industry. They have exported their products to overseas markets as shown in Table 2 above.

On the other hand, the hypotheses testing for relationships of the variables showed in Table 3. This study employed the PLS 3.0 to test the effect for causal paths in the research model. Table 3 tabulates the results of bootstrapping techniques to test for path and hypothesis testing for direct impact of social capital to strategic capabilities. The structural social capital is significantly and positively affect strategic capabilities.

Table 3. Path and Hypothesis Testing for Direct Impact of Social Capital

\begin{tabular}{|c|l|l|l|l|l|}
\hline Hypotheses & \multicolumn{1}{|c|}{ Path } & \multicolumn{1}{|c|}{ Std Beta } & Std Error & \multicolumn{1}{|c|}{ t-value } & \multicolumn{1}{c|}{ Results } \\
\hline H1 & Social Capital -> Innovation Capability & 0.279 & 0.097 & $2.864^{*}$ & Supported \\
\hline H2 & $\begin{array}{l}\text { Social Capital -> Market-Linking } \\
\text { Capability }\end{array}$ & -0.007 & 0.103 & 0.064 & $\begin{array}{l}\text { Not } \\
\text { supported }\end{array}$ \\
\hline H3 & Social Capital -> Marketing Capability & 0.332 & 0.101 & $3.296^{*}$ & Supported \\
\hline H4 & Social Capital -> Technology Capability & 0.240 & 0.105 & $2.286^{*}$ & Supported \\
\hline
\end{tabular}




\begin{tabular}{|l|lll|l|l|l|l|}
\hline H5 & $\begin{array}{l}\text { Social Capital } \\
\text { Capability }\end{array}$ & $->$ & Management & 0.064 & 0.123 & 0.517 & $\begin{array}{l}\text { Not } \\
\text { supported }\end{array}$ \\
\hline
\end{tabular}

Note:*significant at $\mathrm{p}<0.05$, (one-tailed), bootstrapping $(\mathrm{n}=5000)$

The social capital that assigned to strategic capabilities show that several variables have a significant impact on strategic capabilities with t-value $>1,645$. The structural relationships reveal that three of the five hypotheses are supported. They are innovation capability, marketing capability and technology capability with the t-values $2.864,3.296$ and 2.286 respectively.

\section{CONCLUSION AND POLICY RECOMMENDATION}

The results for social capital show that it has a positive and significant impact on three strategic capabilities (innovation, marketing and technology capabilities). The results are supported by previous researchers (Spirkova, Caganova, \& Bawa, 2015), who posited that social capital acts as the source of innovation. This finding echoes those of $\mathrm{Wu}$ and Sivalogathasan (2013), who observed that social networks with outside partners enhance innovation capability. Manufacturing SME exporters in this study share information and learn from one another since they have skills in working together to solve problems. They exchange ideas with people from different areas in their companies and apply their job-related knowledge to other areas in the company to find new opportunities. This is reinforced by several product innovation researchers, who highlighted the importance of creating strong ties with clients and suppliers to enhance the firm's ability to identify market needs and thus, increase its product innovation effectiveness.

Besides, the SMEs' social capital was also found to have a positive and significant impact on marketing capability. Though SMEs focus more on domestic markets, they also participate actively in international exhibitions to build networks. Networking enables the identification and exploitation of market opportunities, which facilitates the development of knowledge-intensive products and firm international market performance (Mort \& Weerawardena, 2006). Indeed, the involvement of a SMEs in strategically-focused supplier may strengthen and integrate resources and capabilities, thus improve international network and positioning (Johnsen, 2007). Additionally, according to experts, the SMEs must take advantage of the international events such as exhibition, seminars, trades, and conferences since these avenues create further networking to gain better information and opportunities (Senik et al., 2014).

Social capital was also found to have a positive and significant impact on technology capability as hypothesized in this study. The manufacturing SMEs in Malaysia apply technology to run their business smoothly. For instance, websites are used to introduce and advertise products, to disseminate information required by customers, suppliers and those eager to know about them. Technology helps them in promoting their business, working unlimited business hours 24-7 and 365 days a year, working without borders, and reduced advertising costs without help from external advertising agents. SME Corp. reported that SMEs are nowadays more technology savvy, having embraced the idea of a digital economy in their businesses (SME Annual Report 2016/2017). They are involved in online businesses and exports, and working towards increasing their efficiency and productivity, thus enabling them to elevate their business to the next level.

Interestingly, social capital does not have a significant impact on market-linking capability. The results contradict several studies cited by Westerlund and Svahn (2008) that suggested the crucial role played by social capital in developing business networks (market-linking) of SMEs. The negative results may happen because employees will engage in external ties (market-linking) 
if there are mutual interest and high levels of trust and reciprocity (Prester, 2015). That is, the market-linking relationship will start only after shared norms are established usually through a longer period of negotiation and probing the potential partner (Dhanaraj, 2006). Additionally, Subramaniam and Youndt (2005) believe that this external connection will result on better performance if there is: common understanding with outside partners, shared objectives and visions, shared common language, similar behavioral rules and norms and common values and culture.

\section{REFERENCES}

Antoniadis, I., \& Charmantzi, A. (2016). Social Network Analysis and Social Capital in Marketing:Theory and Practical Implementation, International Journal of Technology Marketing 11(3), 344-359.

Bondeli, J. V., Havenvid, M. I., \& Solli-Sæther, H. (2018). Placing social capital in business networks: conceptualisation and research agenda. Journal of Business \& Industrial Marketing, 1-24.

Bourdieu, P. (1986). The Forms of Capital, in Richardson, J. (Ed.), Handbook of Theory and Research for the Sociology of Education, Greenwood, Westport, CT, 241-258.

Burt, R. (1992). Structural Holes: The Social Structure of Competition, Cambridge University Press, New York, NY.

Chang, W.S., \& Hsieh, J. (2011). The Dynamics of Intellectual Capital in Organizational Development. African Journal of Business Management, 5(6), 2345-2355.

Coleman, J. S. (1988). Social Capital in the Creation of Human Capital. American Journal of Sociology, 94, 95-120.

Doh, S., \& Acs, Z. (2010). Innovation and Social Capital: A Cross-country Investigation. Journal of Industry and Innovation, 17(3), 241-262.

GAMAGE, S. K. N., PRASANNA, R., JAYASUNDARA, J., EKANAYAKE, E., RAJAPAKSHE, P., GAKNJ, A., ... \& Nedelea, A. M. (2020). Social Capital and SME: A Systematic Literature Review and Research Directions. Ecoforum Journal, 9(3).

Houghton, S. M., Smith, A. D., \& Hood, J. N. (2009). The influence of social capital on strategic choice: An examination of the effects of external and internal network relationships on strategic complexity. Journal of Business Research, 62(12), 1255-1261.

Ismail, K., Ali Jafri, S.K., Khurram, W., \& Soehod, K. (2014). Impact of Social Capital and Firms' Innovative Capability on Sustainable Growth of Women-owned Technoprises (SMEs): A study in Malaysia, World Applied Sciences Journal, 29(10), 1282-1290.

Johnsen, R. E. (2007). The Role of Focal Suppliers in Strategic Networks for Internationalisation: Perspectives from Small and Medium-sized Italian and Thai Silk 
Suppliers. Journal of Fashion Marketing and Managenment, 11(1), 135-147.

Khalique, M., Bontis, N., Shaari, J.A.N.,Yaacob, M.R., \& Ngah, R. (2018). Intellectual Capital and Organisational Performance in Malaysian Knowledge-Intensive SMEs. International Journal Learning and Intellectual Capital, 15(1), 20-36.

Krishen, A.S., Leenders, M.A.A.M, Muthaly, S., Ziołkowska, M., \& La Tour, M.S. (2019). Social Networking from a Social Capital Perspective: A Cross-Cultural Analysis. European Journal of Marketing, 53(6), 12341253.

Lin, N., Cook, K.S., \& Burt, R.S. (2001). Social Capital: Theory and Research, Aldine de Gruyter, Chicago, IL.

Mazzucchelli, A., Chierici, R., Tortora, D., \& Fontana, S. (2021). Innovation Capability in Geographically Dispersed R\&D Teams: The Role of Social Capital and IT Support. Journal of Business Research, 128, 742-751.

Mort, G.S., \& Weerawardeena., J. (2006). Networking Capability and International Entrepreneurship: How Networks Function in Australian Born Global Firms. International Marketing Review, 23(5), 549-572.

Nahapiet, J., \& Ghoshal, S. (1998). Social Capital, Intellectual Capital, and the Organizational Advantage. Academy of Management Review, 23, 242-266.

Parnell, J. A. (2015). Strategic Political Emphasis, Strategic Capabilities and Uncertainty: An Exploratory Assessment of Managers in the United States. Journal of Strategy and Management, 8(1), 41-63.

Prasanna, R.P.I.R, Jayasundara, J.M.S.B., Gamage S.K.N., Ekanayake, E.M.S, Rajapakshe, P.S.K, \& Abeyrathne, G.A.K.N.J. (2019). Sustainability of SMEs in the Competition: A Systemic Review on Technological Challenges and SME Performance. Journal of Open Innovation: Technology, Market and Complexity, 1-18.

Rosli, M. M. (2012). Competitive Strategy of Malaysian Small and Medium Enterprises : An Exploratory Investigation. American International Journal of Contemporary Research, 2(1), 93-105.

Senik, Z. C., Isa, R. M., \& Ayob, A. H. (2014). A Model for Understanding SMEs Internationalization in Emerging Economies. Jurnal Pengurusan, 41, 25-42.

SME Annual Report 2016/2017. (2017). SME Corporation Malaysia - SME Annual Report 2016_17.

Spirkova, D., Caganova, D., \& Bawa, M. (2015). The Social Capital Influence on Enterprise Competitiveness in V4 Countries. Ecic, 314-324. 
Subramaniam, M., \& Youndt, M.A. (2005). The Influence of Intellectual Capital on the Types of Innovative Capabilities. Academy of Management Journal, 48(3), 450-463.

Sulistyo, H., \& Ayuni, S. (2020). Competitive Advantages of SMEs: The Role of Innovation Capacity, Entrepreneurial Orientation, and Social Capital. Contaduría y Administración 65(1) 2020, 1-18.

Wu, X., \& Sivalogathasan, V. (2013). Intellectual Capital for Innovation Capability: A Conceptual Model for Innovation. International Journal of Trade, Economics and Finance, 4(3), 139-144.

Chisholm, A. M., \& Nielsen, K. (2009). Social Capital and the Resource-based View of the Firm. International Studies of Management \& Organization, 39(2), 7-32.

Westerlund, M., \& Svahn, S. (2008). A Relationship Value Perspective of Social Capital in Networks of Software SMEs. Journal of Industrial Marketing Management, 37(5), 492501.

Prester, J. (2015). Intellectual Capital and its Impact on Firm's Performance, 1-8.

Dhanaraj, C., \& Parkhe, A. (2006). Orchestrating Innovation Networks. Academy of Management Review, 31, 659-69.

\section{Copyrights}

Copyright for this article is retained by the author(s), with first publication rights granted to the journal. This is an open-access article distributed under the terms and conditions of the Creative Commons Attribution license (https://creativecommons.org/licenses/by/4.0) 